\title{
Preface
}

Despite the widely recognized importance of the play concept for modern thought and the impressive number of cultural-anthropological and literary studies devoted to play, we still lack a critical historical perspective on the topic. This book, outlining a history of the concept of play in philosophy and science since the end of the eighteenth century, constitutes a first step in contemporary Anglo-American scholarship. The only extensive study related to it (but not available in English) is Ingeborg Heidemann's Der Begriff des Spieles und das aesthetische Weltbild in der Philosophie der Gegenwart (Berlin, 1968). Heidemann, however, confines herself to the phenomenological tradition, adopting mainly a systematic approach, whereas I attempt to provide a historical theoretical model for a much-needed interdisciplinary survey of the field.

The book has three sections. The introduction, "Play, Power, and the Western Mentality," addresses some of the theoretical issues confronting any historical investigation of play in Western thought. I relate my history of the play concept to a history of the Western mentality as a whole, suggesting that this mentality has always fluctuated between various rational and prerational sets of values. Consequently, I draw a distinction between a rational and a prerational group of play concepts, briefly tracing their origins in archaic and classical Hellenic thought. Part I, "Play and Modern Philosophical Discourse," examines the various returns of the play concept in Continental philosophy since the end of the eighteenth century. Initially this concept, which was pushed into the background by the dominant Cartesian tradition of the seventeenth century, finds its way back into metaphysics at the end of the Age of 
Reason, especially through Kant, and then becomes central through Schiller. This first return of the play concept in German idealism, however, restages the repression of prerational play, initiated by Plato and Aristotle and perpetuated by the Neoclassical rationalist tradition. Then, in the wake of Schopenhauer, prerational play itself returns to the philosophical center stage, both through Nietzsche and through such twentieth-century "artist-metaphysicians" as Heidegger, Fink, Gadamer, Deleuze, and Derrida. Part II, "Play and Modern Scientific Discourse," examines, on the one hand, some of the play concepts that surface in modern science in connection with the Darwinian theory of evolution and, on the other hand, the play of scientific discourse itself, as exemplified by the New Physics and the "anarchistic epistemology" in the contemporary philosophy of science. Although the prerational play concepts resurface in modern science as well, here they remain subordinated to their rational counterparts; thus, the play of contemporary scientific discourse, unlike that of contemporary philosophical discourse, remains a predominantly rational one.

Another modern intellectual development closely linked to the return of the play concept(s) in philosophical and scientific discourse is aestheticism. A history of the modern concept of play will have to run parallel to a history of modern aestheticism, and my book attempts to sketch the broad outlines of such a history. Revising the accepted view, I argue that actually there have been not one, but two aesthetic turns in modern thought: one is related to a rational mentality and is initiated by Schiller in the wake of Kant; the other is related to a prerational mentality and is inaugurated by Nietzsche in the wake of Schopenhauer. I also emphasize the radical difference between artistic and philosophical-scientific aestheticism: whereas the first often arises in response to the attempts of philosophy and science to impose their standards on art, the second is an effective way of dealing with the epistemological crises that periodically shake these disciplines, and therefore plays an important role in safeguarding their cultural prestige.

In our methodologically self-conscious age, one can no longer write history from an unbiased, objective, or factual point of view, not least because this point of view has itself become part of yet another methodological model, commonly referred to as "positivism." Thus, history has returned to its hermeneutical roots, and any cultural historical inquiry needs to show itself aware of a dialectic of logical and ideological exigencies, conditioned by the historian's own historicity or relative position vis-à-vis his object of study. The historical approach that I use 
here may be called "interpretive-configurative," and should not be confused with the common hermeneutical approach that nowadays bears the name of "critical rationalism" in philosophy and science and Rezeptionsgeschichte in literary studies. According to the latter historical-hermeneutical model, which can be seen as the latest attempt at reconciling metaphysics with history, the play concept(s) appear, in evolutionary fashion, as a series of interpretations that cumulatively constitute their object ad infinitum. By contrast, in an interpretive-configurative model, the play concept no longer appears as the sum total of its interpretations or as a dialectic of temporality and permanence, but as an incommensurable, discontinuous series of interpretations engaged in a supremacy contest. The history of what we call "play" in the Western world is, then, a history of conflict, of competing play concepts that become dominant, lose ground, and then reemerge, according to the needs of various groups or individuals contending for cultural authority in a given historical period. Therefore, my intention here is not to offer yet another definition of play as "universal" phenomenon, but to show how any definition of play functions in the concrete, historical context of our culture.

Although my book takes into account a fairly large variety of play concepts, it by no means claims to be a comprehensive history of the modern concept of play. Such a history, if it were ever written, would not only reach monumental proportions but could also easily miss its mark. Play is one of those elusive phenomena that can never be contained within a systematic scholarly treatise; indeed, play transcends all disciplines, if not all discipline. Consequently, this volume should be read less as a systematic survey than as a series of loosely connected essays or case studies, combining broad historical theoretical considerations with concrete textual analyses of individual works or key passages within these works. I have chosen to discuss well-known texts because their authors are among the most articulate and persuasive spokesmen for the modern Western mentality. And in addition to such familiar thinkers as Kant, Schiller, Nietzsche, Heidegger, Gadamer, Deleuze, Derrida, Spencer, Freud, Piaget, Bateson, Monod, Planck, Einstein, Heisenberg, Schrödinger, Kuhn, and Feyerabend, my case studies include less familiar figures who have also substantially contributed to the shaping of contemporary consciousness-Eugen Fink, Karl Groos, D. W. Winnicott, Richard Dawkins, Manfred Eigen, René Thom, David Bohm, Hans Vaihinger, and others. I have, moreover, attempted to see all these authors both from within their imaginative worlds and from a 
distance, as key figures who are symptomatic of a whole cultural trend or a whole set of values and beliefs. Thus, even where I deal with familiar works, I believe my interpretations of these works often diverge sufficiently from those currently circulating in the Anglo-American academic community to warrant careful and relatively extensive development.

Finally, because my book attempts to relate the modern concept of play to a history of the Western mentality as a whole, it addresses itself not only to the "play specialist" but also to a considerably wider audience. Through a detailed examination of several Western concepts of play I attempt to offer not so much a critique as a diagnosis of a basic mentality we all share. This diagnosis will perhaps enhance our understanding of ourselves, which may in turn broaden the range of our intellectual and existential choices.

I am deeply indebted to several institutions and to a great number of individuals for having assisted me during the various stages of this project, and I regret that I cannot properly acknowledge all of them here. I am particularly grateful to the Alexander von Humboldt Foundation for its generous support through two crucial years of research and scholarly interaction at the universities of Konstanz and Hamburg. Special thanks are also due to the Andrew W. Mellon Postdoctoral Fellowship Program at Cornell University and its director, Anna Geske, as well as to professors W. Wolfgang Holdheim and William Kennedy for their equally generous support during my tenure as a Mellon Fellow in Comparative Literature at Cornell.

I am no less grateful to Matei Calinescu of Indiana University, Herbert S. Lindenberger of Stanford University, and Virgil Nemoianu of Catholic University, teachers, colleagues, and friends who have closely followed my intellectual development over the years and have critically commented on my work both privately and in print; to Giuseppe Mazzotta of Yale University, for our long and passionate debates about the exiled soul, in wintry Ithaca; to Wolfgang Iser of the University of Konstanz, Karl Robert Mandelkow of the University of Hamburg, and Steven Rendall of the University of Oregon for many delightful and rewarding conversations during my tenure as a Humboldt Fellow; to Joel Black of the University of Georgia and Michael Cahn of the University of Konstanz, for their perceptive critiques of my work; to Albert J. Guerard, René Girard, and David Halliburton of Stanford University for their enlightened and inspiring presence during my years 
at Stanford; to Stanley Fish, Murray Krieger, Edward Said, and Barbara Herrnstein Smith, whose lectures at the School of Theory and Criticism, University of California at Irvine, first led me to thinking about some of the theoretical issues raised in this book; to my colleagues and friends at the University of Georgia, Ronald Bogue, Linda Brooks, Betty Jean Craige, Kent Kraft, Tonglin $\mathrm{Lu}$, and the greatly mourned Frank Warnke, whose genial, cosmopolitan, and witty personality we all miss, as well as to Brian Sutton-Smith of the University of Pennsylvania and Richard Brown of the University of Maryland, for their sympathetic and substantial support during various stages of this project; to the two anonymous readers of my manuscript for Cornell University Press who have offered many useful suggestions and have initiated a spirited debate, helping me further to clarify and sharpen my arguments; to Penny Nichols, Marigene Banks, and Deana Howard for patiently and painstakingly processing several drafts of the manuscript; to Janis Brennan for her generous help with the manuscript, and her loyal friendship through the years; to Jennifer Forbragd, Robert McNamara, and Lisa and Tim O'Brien for their timely assistance at critical moments in the revision of the manuscript; to Alexa Selph for preparing the index; and to Anne Lunt, my copyeditor, and Kay Scheuer of Cornell University Press for their invaluable editorial suggestions.

\section{Athens, Georgia}

Mihai I. SPARIOSU 



\section{Dionysus Reborn}


